\title{
Canadian Mass Timber Demonstration Projects Initiatives
}

\author{
Mohammad Mohammad $^{1 *}$, Julie Tourrilhes ${ }^{2}$, Richard Coxford $^{3}$, and Miranda Williamson ${ }^{4}$ \\ ${ }^{1}$ Senior Research Advisor, Natural Resources Canada, Canada, \\ ${ }^{2}$ Co-op Engineering Student, Natural Resources Canada, Canada, \\ ${ }^{3}$ Program Officer, Natural Resources Canada, \\ ${ }^{4}$ Program Manager, Natural Resources Canada \\ *Corresponding author's e-mail: mohammad.mohammad@canada.ca
}

\begin{abstract}
In order to expedite market acceptance and facilitate the commercial uptake of wood products and systems in Canada, it is necessary to showcase such applications through high-rise and nonresidential building demonstration projects. This paper presents recent initiatives by the Government of Canada focused on increasing use of wood as a green building material in infrastructure projects by supporting such demonstration projects. The objective of Green Construction through Wood (GCWood) program (launched in 2017) is to support the design and construction of several high-rise and non-residential timber demonstration buildings and bridges in Canada through expression of interest (EOI) calls. The program is also supporting research and development activities to facilitate acceptance of provisions that would allow for the construction of tall wood buildings in Canadian building codes and advanced wood education at engineering and architectural colleges and universities to help develop the future design capacity in Canada.
\end{abstract}

\section{KEYWORDS}

Tall wood buildings; Demonstration projects; Mass timber, Building codes; Wood education.

\section{INTRODUCTION}

Building with wood is now being recognized as a viable option by designers, builders, developers, governments and other stakeholders all over the world, including those in Canada. This is made possible by the recent advancement in the development of engineered wood products, connection and building systems, prefabrication technology, and the interest in using wood due to its environmental benefits. It was recognized that in order to support and facilitate acceptance for wood products and systems in Canada, it was necessary to showcase the use of wood in high-rise applications. This triggered the 2013 Tall Wood Building Demonstration Initiative (TWBDI) by Natural Resources Canada (NRCan) which supported the design and construction of two tall wood buildings demonstration projects in Canada. The success of the TWBDI led to new initiatives by the Government of Canada that further encouraged the design and construction of timber buildings in the high-rise applications, low-rise non-residential construction and bridges. This paper presents details on the design and construction of two tall wood buildings demonstration projects funded by the Government of Canada and highlights the new initiatives launched to support activities focused on expanding use of wood in non-traditional applications. 


\section{ADVANCEMENT IN MID-RISE WOOD FRAME CONSTRUCTION IN CANADA}

Until recently, the National Building Code of Canada (NBCC) restricted the widespread use of wood in buildings taller than four storeys. Taller and larger wood buildings beyond the prescribed code limits on height and area could still be designed and constructed under the "Alternative Solutions" path in the NBCC and corresponding provincial codes. However, such a process puts the onus on designers to demonstrate equivalency and compliance with code provisions through testing, modelling and rigorous engineering analysis. Over the past 10 years, however, extensive research has been conducted by Canadian research organizations such as National Research Council of Canada (NRC), FPInnovations and universities to support the development of mid-rise wood frame building applications. In 2009, the Government of British Columbia became the first Canadian jurisdiction to allow the construction of mid-rise residential wood structures up to six storeys after it amended its provincial building code. The valuable knowledge, experiences gained through this process and additional research were shared with other Canadian provinces such as Ontario, Québec, Alberta and Nova Scotia, and with the NBCC code committees. This led to the adoption of mid-rise wood frame construction in those provinces as well as the 2015 edition of the NBCC (NBCC, 2015). Currently over 650 mid-rise wood frame buildings have been built, are under construction or are at the planning and design stage across Canada.

\section{NRCAN'S TALL WOOD BUILDINGS DEMONSTRATION PROJECTS}

NRCan's TWBDI, launched in 2013, led to the construction of two tall wood buildings. The first is an 18-storey hybrid mass timber student residence located in Vancouver, which was the world's tallest hybrid wood building when completed. The second is a 13-storey residential building in Québec City. NRCan funded the critical incremental R\&D activities required to design, approve and construct two demonstration buildings. NRCan funding was leveraged by provincial and forest industry funding. More details about NRCan's 2013 TWBDI can be found in the proceedings of the 2018 World Conference in Timber Engineering (WCTE) (Mohammad et.al., 2018).

\section{Incremental R\&D Activities}

Since the approval process for tall wood buildings in Canada is currently done under the "Alternative Solutions" provisions specified in Canadian building codes, design teams are required to demonstrate that their tall wood building projects design can meet or exceed existing performance levels specified for similar code-compliant non-combustible construction. To facilitate the regulatory approval and support the design of selected tall wood building demonstration projects, NRCan, together with provinces and industry, funded specific eligible incremental R\&D activities. Those activities can be grouped into four main categories:

1) Preliminary design and research leading to a building permit, including the development of design concepts, fire protection and safety strategies, and code alternatives.

2) Detailed structural, fire, and acoustics design of the demonstration projects and any additional testing required by the Authorities having Jurisdictions (AHJs).

3) Construction issues such as logistics, erection, construction site safety, weather protection, and risk management in relation to fire during construction.

4) Post construction activities including communication, instrumentation and monitoring.

The following sections provide details on the design and construction of the two tall wood buildings demonstration projects funded by NRCan under the 2013 TWBDI. 


\section{UBC Brock Commons: 18 storey tall wood building, Vancouver}

UBC Brock Commons Tallwood House is a hybrid structure (17 storeys of mass timber construction on top of one concrete storey, in addition to two concrete shafts). The building is a mixed use residential complex (residential occupancy, Group C, with subsidiary assembly spaces, Group A-2). Student housing is located on levels 2 through 18 of the building, with two quad units per floor on levels 2 through 17, located at either end of the building, and 16 studio suites. The building was completed in June 2017 at a total cost of CDN\$51.5 million. NRCan contributed over $\$ 2.3$ million in support the design and construction of the demonstration building.

The building structural design concept adopts the typical "slab-on-post" commonly used in concrete design with no beams, using CLT floors and glulam and parallel strand-laminated timber (PSL) posts. This design capitalizes on the unique 2-way action capability of CLT plates and lead to maximizing clearance between floors and ceilings. The building is supported on a foundation comprising of reinforced concrete footings, below grade shear walls and columns, and a raft slab. Reinforced concrete columns support the second level transfer slab and the two 18-storey reinforced concrete shafts provide structure for building stairs, elevators and services. To avoid a vertical load transfer through the CLT floor panels (i.e., excessive compression perpendicular to grain stresses), an innovative steel connector was developed that allows for a direct gravity load transfer from higher- to lower-storey columns and down to the concrete foundation. The steel connector also provides a bearing surface for the CLT floor panels (Figure 1). The innovative, 2way point-supported CLT floor system was evaluated at FPInnovations. Testing was conducted to provide the design team with information on the structural performance of the floor system under gravity loads. Two concrete cores provide the primary lateral support for earthquakes in the building, allowing the building to exceed current building code limits for seismic performance. Steel drag plates and straps, fastened to the CLT floor plates and bolted to cast-in embed plates, drag CLT diaphragm forces into the cores. Other design elements also addressed were axial column shortening, dynamic and wind-induced vibrations, and progressive collapse.
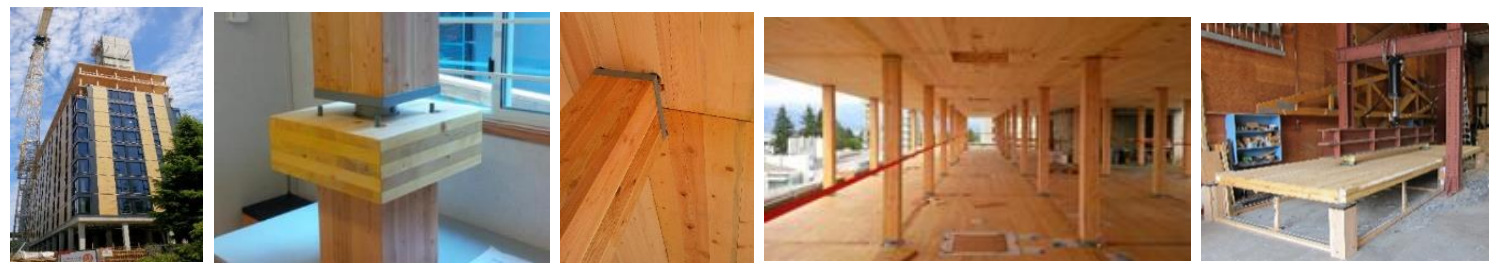

Figure 1. CLT slab-on-post structural system adopted for the UBC Brock Commons and monotonic tests conducted at FPInnovations (courtesy of naturallywood and FPInnovations)

\section{Construction Process}

The building envelope consists of a curtain wall at level 1 and a prefabricated panel wall system on levels 2 through 18. The prefabricated steel-stud panel system includes weather-proof gypsum sheathing panels, applied to the exterior of the steel studs, air and water membrane, exterior highdensity semi-rigid stone-wool weather and thermal insulation board, applied to the sealed gypsum sheathing panels; and high-pressure laminate panel cladding, consisting of 70 per cent wood-based fibres and resin (Trespa ${ }^{\circledR}$ panels) as the finished cladding. Windows were installed before delivery. In order to demonstrate and validate the design and construction concepts, a two-storey mock-up was built off-site (Figure 2). The mock-up enabled the design and construction team to examine the process of constructing the prefabricated structural and building envelope components 
and the constructability of connections. 3D modelling was used during the early stage of design to facilitate integrated design and construction efforts. A 4D simulation of the installation sequence, developed for the 3D virtual model, provided an overview of the assembly of various building elements. The mass timber super-structure was assembled in just 9.5 weeks.
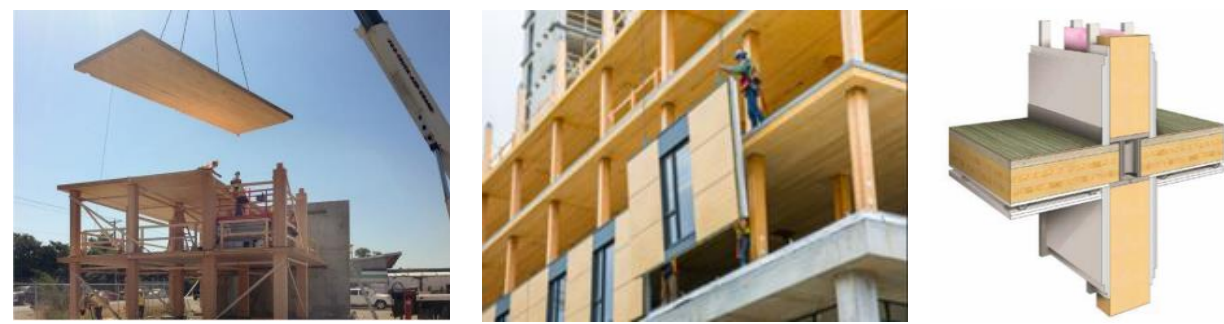

Figure 2. Two-storey mock-up, exterior prefabricated panels being installed and details of the encapsulation of CLT floor (courtesy of Naturallywood.com and Acton Ostry Architects Inc)

\section{Fire Safety Strategy}

The fire safety design of the Brock Commons building underwent a $3^{\text {rd }}$ party peer-review process that involved leading fire code experts, researchers, AJHs and firefighters. The building itself is comprised of a series of repetitive, compartmentalized small rooms so that in the event a fire, it would be contained in the compartment in which it originated. Brock Commons has been designed to meet the fire-resistance ratings required of a non-combustible construction. The fire resistance of CLT, glulam and LSL components used in the project has been achieved through encapsulation, with 3 to 4 layers of fire-rated type X gypsum board, dependent on location. Moreover, sprinkler systems were designed with back-up water and emergency power supply so the sprinkler system will continue to function, even if the building's standard water and electrical systems are shut down. NRCan funding supported fire testing and the fire protection measures.

\section{Code Approval of the Brock Commons Tall Wood Building}

In British Columbia (BC), the Building Code allows the construction of wood buildings as high as six storeys. However, under BC's Building Act, a site-specific regulation (SSR) can be issued to approve a taller wood building on a particular building site with special safety requirements to ensure it will meet all safety performance levels. After consultation with the BC Building Safety and Standards Branch (BC BSSB), an SSR was developed that set safety standards for the building including enhanced fire and seismic levels. Some of the specific provisions included; enhanced seismic design of the concrete foundation and stair/elevator shafts; enhanced fire protection strategies; and peer review of the detailed design. More details on the UBC Brock Commons can be found in the WoodWORKS! case study (WoodWORKS!, 2018)

\section{3-storey Tall Wood Condominium Tower (Origine), Quebec City}

The 13-storey Origine condo building in Québec City is the 2nd demonstration building funded by NRCan. The residential tower is the tallest wood building in eastern Canada and the tallest all wood construction condo tower in North America at 40 metres. The building includes a 12-storey mass timber super-structure on top of a 1-storey concrete podium. The mass timber super-structure is a combination of CLT shearwalls, elevator shafts and stairwells and floors, with glulam posts and beams supporting the CLT floors. The overall cost of the building was CDN \$22 million. 
While the Brock Commons used concrete shafts as the main vertical lateral load resisting system (LLRS), the Origine building relied on a combination of massive balloon-type CLT shearwalls (9 plies) and elevator and staircase shafts made of CLT (Figure 3). The lateral load resisting system is comprised of seven main shearwalls made from CLT. The CLT floors act like a diaphragm to transfer lateral forces to shear walls. Massive steel holddowns were used at the interface between the concrete podium and the base of the shearwalls. CLT shearwalls and elevator shaft walls were delivered in 3-storey high sections. CLT panels were connected with shear keys made of thick steel plates to provide some ductility and energy dissipation between one panel and the other.
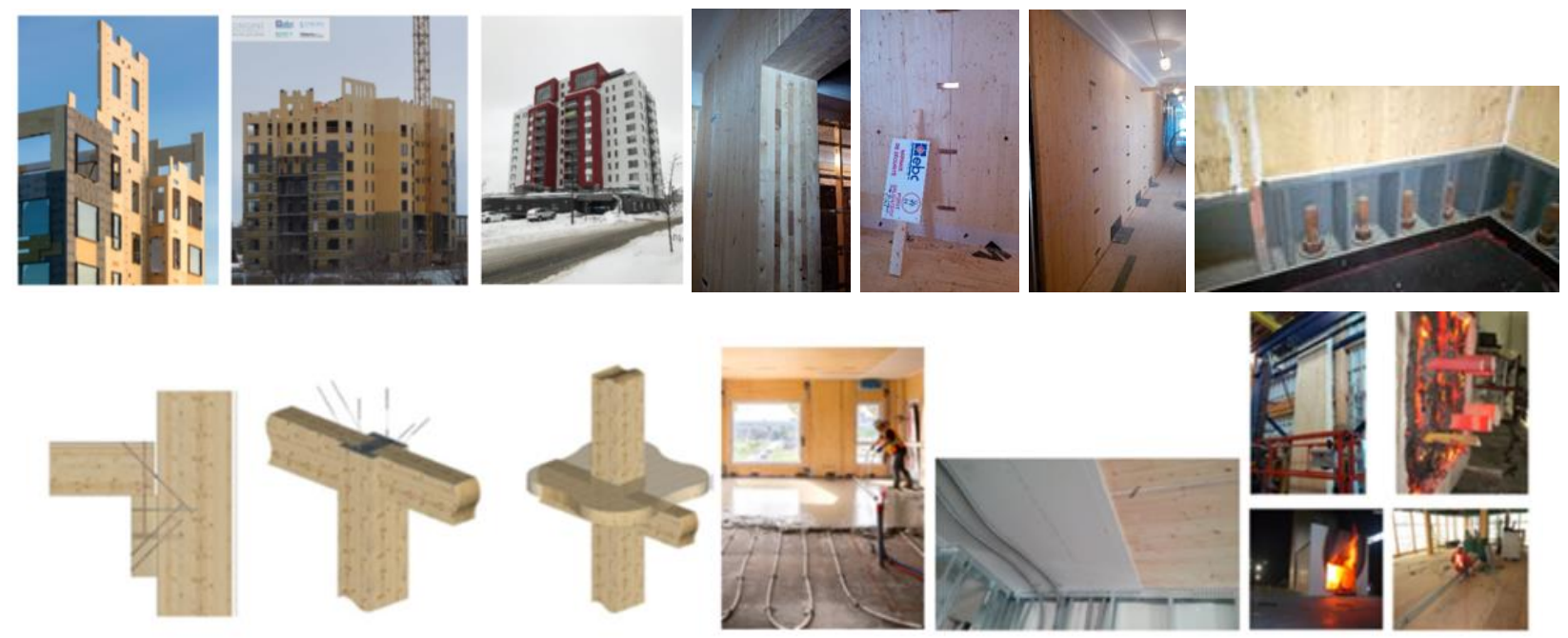

Figure 3. Quebec's 13-storey building: details on CLT shearwalls, holddowns, connections and fire and structural testing (courtesy of Stéphane Groleau, Nordic Structures and FPInnovations ).

The Origine building mainly used post and beam system where the CLT floor was supported by glulam beams spanning between glulam columns. The glulam posts were continuous from one storey to another to ensure a continuity in the vertical load path. Since the CLT shearwalls and the walls of the elevator and stairwell shafts were continuous through the height of the building, glulam ledgers were bolted and screwed to the continuous walls to provide support to the CLT floor at the perimeter of the building (Figure 3). On the first floor, the glulam posts are secured to the reinforced-concrete podium using steel plates anchored in the concrete with $3.6 \mathrm{~m}$ long steel rods. More details about the structural design concept can be found in Cecobois' case study (Cecobois, 2018). The building was designed using "Alternative Solutions" provisions in the Québec's building code and is also based on FPInnovations' "Technical Guide for the Design and Construction of Tall Wood Buildings in Canada", developed with NRCan funding to facilitate the design of tall wood buildings in Canada (Karacabeyli, 2014). In approving the Origine tall wood building in Québec, AHJs in Québec worked with FPInnovations to outline the technical principles required to design and construct wood buildings up to 12 storeys using mass timber. This led to the publication of the technical guide entitled Mass timber buildings up to 12 Storeys: Directives and Explanatory Guide in 2015. The Government of Québec became the first jurisdiction in North America to allow the construction of tall mass timber buildings (Government of Québec, 2015).

Construction Process 
It took only four months to erect the wooden super structure as the construction of the building relied heavily on prefabrication of the CLT panels, glulam columns, and connections. The various trades (plumbers, electricians, etc.) were able to get to work inside the building long before the roof was set in place, proceeding in a designed sequence that was repeated from floor to floor. The first trades to work in the building insulated the walls and the pipes for the radiant floor heating before concrete topping is poured (Figure 3). To address concerns over potential construction fires due to exposed mass timber prior to full encapsulation, glulam and CLT walls and ceilings were partially encapsulated with a single layer of gypsum board a few floors below the actual floor where construction was taking place. This was followed by a full encapsulation as per the design.

Research and Development to Support the Design and Approval Process

NRCan funding was used to support extensive fire, structural, connections, and acoustic testing carried out in support of the design and approval of the Origine project. Fire resistance tests on typical encapsulated CLT wall and floor assemblies in addition to a full-scale exterior wall test as per the design, were carried out at the NRC to demonstrate the $2 \mathrm{hrs}$ fire resistance rating required by the building authorities in Québec. To facilitate approval of the combustible mass timber exit stair and elevator shafts, a large-scale demonstration fire was performed to evaluate the fire performance of a full-scale three-storey mass timber shaft (Figure 3). The demonstration was successful and led to approval of the mass timber shaft and the associated fire protection strategy. Extensive structural and connections tests were also carried out in support of the design. More details about the testing carried out in support of the design and approval of the Origine can be found in Mohammad et. al. (2018).

\section{GOVERNMENT OF CANADA'S SUPPORT FOR WOOD CONSTRUCTION}

The government of Canada is continuing its efforts to advance the market and regulatory uptake of wooden high-rises following the conclusion of the 2013 TWBDI. Budget 2017 provided funding of \$39.8 million over 4 years under the Pan-Canadian Framework on Clean Growth and Climate Change, starting in April 2018, to increase the use of mass timber as a greener construction material in buildings and public infrastructure projects. As a result, a new program - the Green Construction Through Wood (GCWood) was announced. The program has three key components: wood and hybrid/wood demonstration projects (high-rise, low-rise non-residential and bridges), building code revisions and supporting research and technology transfer and advanced education.

\section{Wood and Hybrid Wood Demonstration Buildings}

To continue promoting the use of wood in tall buildings, an EOI was launched by GCWood in October 2017, targeting buildings of 10 storeys and taller. NRCan received 14 proposals in total from across Canada. A panel comprised of Canadian experts evaluated the applications. Proposal evaluation and ranking was based upon an established set of criteria that examined the innovation and replicability of the wood-based building system among other things. NRCan, with input from the expert review panel, short-listed the proposals that had the potential to showcase new and advanced wood products and applications. Several contribution agreements have been established with the short-listed tall wood projects, with an official funding announcement to come. A second EOI call for proposals targeting low-rise non-residential construction projects up to 4 storeys tall was launched in early November 2018. In total, 30 applications were received by NRCan and an expert panel reviewed and evaluated the various proposals in February 2019. Many of the proposals are pushing the envelope in terms of adoption of advanced design and construction technologies using wood-based products and systems. 
MOC SUMMIT / MAY 2019

\section{Supporting Revisions to Canadian Building Codes}

The GCWood program has been providing significant funding to support current and future proposed revisions to the 2020 and 2025 editions of the NBCC to allow tall wood buildings beyond the current limit of 6 storeys, ultimately targeting a performance-based code in the 2025 edition.

\section{Adoption of Tall Wood Buildings in Canadian Building Codes}

The 2015 edition of the NBCC includes some significant changes with respect to wood design as it permits 5- and 6-storey tall wood frame buildings (NBCC, 2015). A code change proposal for the 2020 edition to include 12-storey tall mass timber was submitted by the Canadian Wood Council (CWC) to the NBCC Code Committee for their consideration. A Task Group and several Working Groups were established to discuss the proposed code change, identify potential issues, research needs and provide recommendations to the NBCC Standing Committee on Fire Protection (SC-FP). The current code change proposal is recommending a new type of mass timber construction called "Encapsulated Mass Timber Construction", or EMTC. EMTC is that type of construction in which a degree of fire safety is attained by the use of encapsulated mass timber elements. The code change proposal was posted for public review in November and December of 2017 and the Task Group addressed public comments in March 2018 and provided recommendations to the Canadian Commission on Building and Fire Codes (CCBFC) Standing Committees, which considers all comments and will make final recommendations. A $2^{\text {nd }}$ public review was posted in December 2018 and January 2019 and comments were addressed again by the Task Group. Subject to approval by the CCBFC, the final changes could be published in the 2020 edition of the NBCC. While the 12 storeys EMTC proposal is focused on the fire performance that corresponds to Part 3 of the NBCC, there are some parallel work items being discussed at other Standing Committees of the building code that addresses the lateral load resisting systems using CLT. NRCan is currently funding the development of a Canadian Construction Material Center (CCMC) technical guide for shearwalls (including balloon type) in tall mass timber buildings. The technical guide will provide a procedure for the evaluation of the performance of Seismic Force Resisting Systems and how to determine their force modification factors.

\section{NRCan's Support to Research and Development Activities at NBCC}

A large number of research and knowledge gaps were identified by the NBCC code committees and Task Group related to fire protection. Several research projects were initiated at the NRC to address those gaps and support the proposed code change provisions. The proposed code change on EMTC for the 2020 edition of NBCC has some provisions on the amount of mass timber that can be exposed based on existing research conducted in Canada that was available at the time of proposal submission. The available research indicated that there are several factors to be considered, including the amount of exposed wood and the configuration of the exposed wood (e.g., exposures to mitigate re-radiation effects), and was used to estimate the amount of exposed wood that would be permitted in the code change proposal. However, there were still some research gaps for technical data to confirm and form the basis for the allowance of exposed mass timber in the EMTC buildings. To provide science-based data to quantify the amount of mass timber that could be exposed in an EMTC building, a series of fire tests were initiated at NRC with funding from NRCan. Room fire tests included exposed mass timber for walls and ceilings (different percentages of exposed area were selected for each fire test) and with exposed mass timber for ceilings, beams, columns and arches (Figure 4). NRC fire scientists have shared results of the fire testing with the Task Group and the NBCC SC-FP code committee. Additional fire testing is being conducted at NRC using other types of mass timber products including NLT. 


\section{Advancing Wood Education and Technology Transfer}

The GCWood program is funding activities to support the implementation of advanced wood design education at Canadian universities and colleges, and facilitate the development of design and Life Cycle Assessment (LCA) tools and data to assist designers and builders. More details about NRCan's new GCWood program can be found at: www.nrcan.gc.ca/gcwood
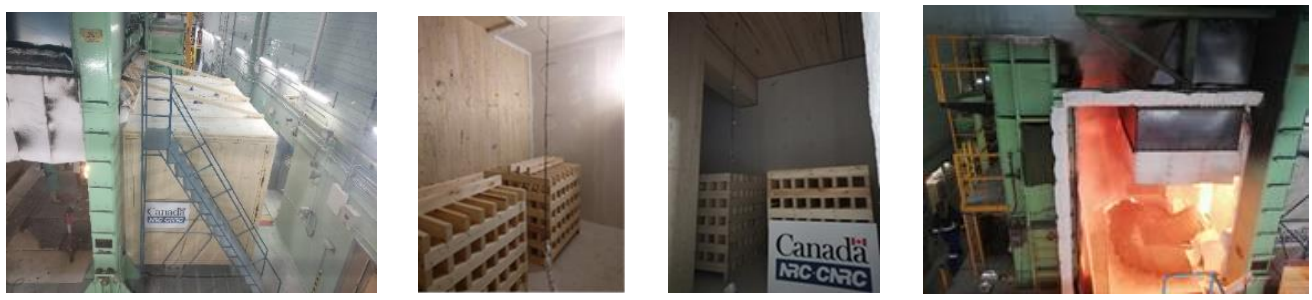

Figure 4. CLT and NLT room fire testing to validate percentage exposed mass timber conducted at NRC for EMTC code proposal targeting the 2020 edition of the NBCC.

\section{CONCLUSION}

Canada has been recognized as a leader with a successfully developed multi-disciplinary research capacity in wood building systems, and possessing a critical mass of design and construction firms, as well as manufacturing capacity. Canada's Tall Wood Demonstration Initiative has had a huge impact and led to the design and construction of two unique tall wood buildings. The Government of Canada continues to invest in new programs such as GCWood to facilitate broader market and regulatory acceptance of mass timber and tall wood buildings through demonstration projects and the adoption of tall wood buildings in the Canadian building codes.

\section{REFERENCES}

Cecobois. Origine Pointe-Aux-Lièvres Ecocondos Quebec City. Case study developed by Cecobois, Québec City, Québec, 2018.

Gagnon, S. and C. Pirvu, Editors. CLT Handbook. Canadian Ed. FPInnovations Special Publication SP-528E. Québec, Québec, 2011.

Government of Québec. Mass timber buildings up to 12 Storeys: Directives and Explanatory

Guide. Régie du bâtiment du Québec, Québec, 2015.

Karacabeyli, E. and C. Lum, Editors. Technical Guide for the Design and Construction of Tall Wood Buildings in Canada. FPInnovations. Special Publication, SP-55E, Canada. 2014.

Mohammad, M.; Robert Jones, Maureen Whelan, Richard Coxford. Canada's Tall Wood Buildings Demonstration projects. Proceedings of the 2018 World Conference on Timber Engineering (WCTE), Seoul, Korea, 2018.

National Research Council. National Building Code of Canada (NBCC). National Research Council of Canada, Ottawa, Ontario, 2015.

WoodWORKS! Brock Commons Tallwood House: UBC Vancouver Campus- The Advent of Tall Wood Structures in Canada. Case study by the Canadian Wood Council, 2018. 